\title{
RESOURCE BASED LEARNING FOR TEACHING AND LEARNING ENGLISH IN DIGITAL ENVIRONMENTS
}

\author{
Muhammad Nazil Iqdami \\ Masters of Education, The University of Georgia, USA \\ iqdami25@gmail.com
}

\begin{abstract}
This paper presents a conceptual framework on the implementation of Resource Based Learning (RBL) in English as a Foreign Language (EFL) class. Resource based learning emerges as the proponent of constructivism as well as a response to the rapid development of information and communication technology (ICT) and its influence in education. Digital technologies pose potential opportunities in changing the face of education. The affordances of digital technologies empower more student-centered learning and more accessible educational information. Teaching English for foreign learners is dynamic and requires innovations. Admittedly, most English learners in Indonesia need more exposure to authentic English learning resources, and digital technologies are very potential in accommodating their needs. Resource based learning sets an innovative framework and systematic approach for English educators in designing digital technology-based instructions.
\end{abstract}

Keywords: Resource based learning, digital technologies, constructivism, English as a Foreign Language 


\section{INTRODUCTION}

The World Bank (2016) recently releases a report that the literacy rate of people in Indonesia reaches $92.8 \%$. Additionally, the internet users in this vast country increase significantly as more than fifty million Indonesians now have direct access to the internet (World Bank, 2016).These numbers indicate that literate Indonesians are catered with abundant digital information and resources of learning. The very crucial question emerges is whether or not Indonesians have exploited this imposing opportunity maximally.

The nature of digital technologies has changed dramatically as a wide range of learning systems now leverage information from digital world to address diverse epistemological beliefs and intended learning goals despite its unknown origin and quality (Hill \& Hannafin, 2001).Consequently, many educators and experts in various subjects, including English, have been intrigued to find ways in integrating digital technologies in teaching and learning. In English teaching and learning, more modern methods are proposed and they all seem promising. Mobile-based language learning, for instance, is believed to improve English content delivery, learner-to-learner interaction, and vocabulary acquisition (Bachore, 2015). Similarly, virtual English learning environment empirically enhances students' language learning autonomy(Bailly, Ciekanski, \& Guély-Costa, 2013). In addition to emerging methods in English teaching and learning, a number of professional organizations have also devoted to creating mobile and desktop applications such as CALICO, EUROCALL, Duolingo and IALLT(Chun, Smith, \& Kern, 2016).

Many might highly appreciate the positive development in English teaching and learning in light of the advancement of digital technologies. On the other hand, language teachers and learners should not forget that they can rely on other forms of technology they are already familiar with(Chun et al., 2016).If not careful, language teachers and learners can easily get lost in immense world of digital technologies. When that happens, opportunities afforded by digital technologies will go to waste.

The penetration of digital technologies in English teaching and learning in Indonesia is admittedly outperformed. Despite its great number of users as reported by the World Bank, 
digital technologies are still considered as add-ons to traditional English teaching methods. According to Son, Robb, and Charismiadji (2011), teachers' lack of digital competency is amongst several imperative factors that inhibits teachers to develop digital technology-related English pedagogies. However, this should not be an excuse and teachers' beliefs (Richards, 1998, p. 66)in great potential of digital technologies in teaching English must be emphasized.

This paper aims at exploring the concept of resource based learning (RBL) in teaching and learning English as a foreign language in digital environments. The exploration of RBL is based on three rationales. First, digital technologies democratize access to information(Giroux, 2010; Kellner, 2003). Thus, English learners from every corner of the world have the same opportunity to obtain resources of English teaching and learning from their own desks. Second, English undisputedly dominates digital contents as it is the most used language in the internet(Nunan, 2003). Simply put, internet users are exposed to English on so many levels. Third, the use of digital information in English teaching and learning has not been properly structured.

This paper begins by discussing the nature of RBL along with its supporting theories. Subsequently, the examination of RBL practices in education will be presented. Finally, conceptual implementation of RBL on teaching and learning English as a foreign language in digital environments will be discussed comprehensively.

\section{DISCUSSION}

\section{Emergence of Resource Based Learning}

Learning resources involve a wide range of forms. However, printed materials such as books, journals, reports, periodicals, and documents are thought of the most regular and legitimate resources(Maddux \& Johnson, 1997). Most teachers, if not all, idolize textbooks as their primary support in delivering lessons to students. As a consequence, certain textbooks become very authoritative that the only reliable knowledge is what is written in these textbooks. 
In turn, it is very easy to predict that these textbooks become very dominant and commercialized(Reigeluth \& Squire, 1998).

Resource based learning (RBL) emerges as a response to offering learners with myriad sources of knowledge that were once limited prior to the advancement of digital technologies. In pre-digital environments, resources were passive, produced by certain parties, and used in congruence with very specific and formal educational goals(Hannafin \& Hill, 2007). Conversely, current digital environments have advanced both the nature of resources and information and the way our society learns(Galbreath, 1997). Consequently, our daily playgrounds such as homes, schools, libraries, workplaces, and public spaces become the center of learning resources.

According to S. Brown and Smith (1996, p. 1), RBL is an approach to pedagogy in which learning resources are extensive and enable students to learn independently apart from learning mediated by teachers. This early definition posits an idea that students' learning resources can be anything that enhances students' independent study. In line with this definition, Hill and Hannafin (2001)further assert that potential learning resources include media, people, places, and ideas. At this point, the word "media" is emphasized because it encompasses not only printed materials such as books but also any devices that convey information to learners. More specifically, the word "media" is purposely used to accommodate the affordance of digital technologies.

Theoretically, the emergence of RBL is influenced by constructivism. Constructivism theory sets a foundation for many modern approaches of teaching such as task-based learning, problem-based learning, project-based learning, inquiry-based learning, case-based learning, and many more. Jean Piaget (1896-1980) and Lev Vygotsky (1896-1934)are considered as founding fathers of constructivism(Duncan, 1995). Although Piaget's and Vygotsky's stresses on constructivism are epistemologically different, they share similar philosophical view that humans' knowledge is constructed through the interactions of experiences, ideas, and society(Cunningham \& Duffy, 1996). The grounding assumptions of constructivism include: (1) all knowledge is constructed and learning is a process of construction; (2) many world views can be constructed so that there will be multiple perspectives; (3) knowledge is context dependent 
and it should occur in contexts to which it is relevant; (4) learning is mediated by tools and signs; and (5) learning is an inherently social-dialogical activity (Cunningham, Knight, \& Watson, 1994; Savery \& Duffy, 1995).

Resource based learning is the proponent of constructivism in a way that it encourages learners to explore and construct new knowledge depending on their own needs. From the digital technologies stand point, RBL is inferred as the use and application of available assets to support varied learning needs across contexts (Beswick, 1979; Doiron \& Davies, 1998; Hannafin \& Hill, 2007; Haycock, 1991). After all, RBL is not a learning pedagogy, but instead it is an approach to a process through which epistemologically different, but grounded, learning models are enacted (Hannafin \& Hill, 2007). Thus, RBL should be positioned as an alternative approach that can be embedded into any learning models, preferably constructivism-related models.

The issue brought to the table by the proponents of RBL is that information from digital technologies should be considered as integral learning resources. Textbooks seem to dominate learning resources because of their congruence with established curriculum objectives (Breivik, 1996). However, with the advancement of digital technologies, information in these environments is not only massive but also growing exponentially accurate(Hannafin \& Hill, 2007).

It is very promising nowadays to see that blogs, wikis, and other web 2.0 forms are growing to become an essential source of information across a wide range of learners. Part of the reasons is because information in digital technologies is easy to access, share, and produce (Counts, 2006). Additionally, digital technologies make it possible for users to access public information such as historical documents, weather information, and government reports(Hannafin \& Hill, 2007). This information was once impossible to access by publics because it was kept at centralized repositories that were far away from them. Thus, RBL emerges as a systematic approach to help teachers and students maximally make use of the power of digital technologies to help them construct knowledge that is aligned with educational objectives. 


\section{Case of Resource Based Learning in Education}

Many creative educators have eagerly integrated RBL in their classrooms. They perceive it as a malleable approach they can integrate within their epistemological beliefs. Teachers and students begin to consider digital contents as their primary resources of learning. YouTube, for instance, provides flexible and handy learning resources for everyone and everywhere (Clifton \& Mann, 2011; Duffy, 2008; Lee \& Lehto, 2013; Tan, 2013). YouTube-like websites such as Khan Academy and Laerd are very popular among mathematics and statistics learners(Thompson, 2011). Not to mention a tutorial website such as Lynda has been subscribed by hundreds of universities worldwide to help students enhance their media-related skills(Dybvik, 2008). These are all authentic evidences that digital technologies have significantly contributed to a new face of education.

Despite the promising power of digital technologies in education, questions related to literacy, misinterpretation, propagandizing, and integrity remain critical(Brooks, 2003; Harp \& Tremayne, 2006; McPherson, 2006). Thus, RBL emerges as an alternative to close the gap between the power of digital technologies and these questions. A number of researches on the implementation of RBL have been conducted to investigate its heuristics and implications in education.

A research on the implementation of RBL in a teacher development program was conducted by Yu, Abrizah, and Sani (2016). Their research was part of programs to improve Malaysian teachers' information literacy. Through RBL, they investigated how teachers conceptualized information literacy and disseminated their information literacy in classrooms. They found out that teachers' understanding of information literacy accounted for their teaching activities and that teachers were well-prepared to implement resource-based assignments in their classrooms.

Another case study on the implementation of RBL was carried on by So and Ching (2012) in a science class. In their study, science teachers designed their class based on components of RBL such as choices of contexts, selections of resources, tools, and scaffoldings. It was revealed that RBL significantly helped teachers design their learning environments with 
online resources. Additionally, teachers became more aware of online resources selections and students' need for an assistance through scaffoldings. In general, RBL approach not only attracted but also motivated science students to inquire their own scientific knowledge.

Kononets (2015)also shared her experience when implementing RBL in an agriculture class. Her research was an attempt to create e-learning resources for her students. Given her elearning resources were hosted freely, she found out that RBL helped integrate the combination of traditional and more innovative forms of resources. She added that the quality of e-learning resources could be developed through collaborations as these were sharable and available online

The opportunity of RBL in education is considerable. Teaching and learning English as a foreign language might embrace this approach to not only achieve instructional goals but also maximally take the advantage of digital resources. The following section discusses the conceptual framework of implementing RBL in an English as a foreign language (EFL) class.

\section{Resource Based Learning and Instructional Design}

The implementation of RBL in an EFL class, like any other classes, follows the principles of instructional design if RBL is to facilitate intentional learning(Branch, 2008, p. 6; Gagné, Wager, Golas, \& Keller, 2005, p. 1). According to Hannafin and Hill (2007)and Butler (2012), three components need to be prepared prior to designing RBL instructions. The first component is contexts. Contextsin RBL includeexternal contexts, individual contexts, and negotiated contexts. External contextsunderline learning expectations, problems, and goals that a teacher or an external agent, e.g. government, determines. In the Indonesian context, learning goals have to meet the standards of national curriculum. Individual contexts offer students to explore their unique needs and goals. This is where students are encouraged to set their personal goals in learning English and how they will achieve the goals. In negotiated contexts, students are given choices of general goals and they decide their own specific goals that are unique to their interests(Hill, Domizi, Hannafin, Kim, \& Kim, 2007). 
The second component is tools. Tools play an essential role in RBL because they are used by learners to engage with information from digital environments. Tools can be used in multiple contexts and goals, and their functions vary across learning models (Hannafin \& Hill, 2007; Iiyoshi, Hannafin, \& Wang, 2005). Processing tools are instrumental in organizing cognitive loads related to learning models. In an EFL class, tools such as bookmarks can support different constructivism-related learning models. Searching toolsare very flexible in both directed and learner-centered learning models. Teachers can assign students to search for English materials on the World Wide Web environments using search engines such as Google, Yahoo, MSN, and others. Manipulation tools empower students in analyzing, evaluating, and synthesizing information gathered from the digital environments. Applications such as Duolingo, British Council's LearnEnglish Grammar, and Babbelcan help students manipulate their own learning. Finally, communication toolsreinforce learner-to-teacher and learner-to-learner communications in exchanging information. Blogs and wikis have been used by English teachers and learners to exchange information and collaborate in grammar, reading, and writing classes.

Scaffolds are the third component of RBL. Hannafin and Hill (2007)defines scaffolding as teachers' support to students' learning that subsequently fades away in a continuous cycle as students' knowledge develops. The needs for scaffolding vary among students depending on students' aptitude, problems encountered, and learning contexts (Sharma \& Hannafin, 2007). Resource based learning recognizes four types of scaffolds. First, procedural scaffolds guide students how to apply features and functions of certain source. When a teacher introduces an English application such as Duolingo, he/she needs to familiarize students with its components and functions. Conceptual scaffolds are teachers' efforts to help students in making connections between information in digital environments and pre-defined learning goals. Not only does a teacher ask students to find a grammatical answer from a certain website, but also he/she needs to give an understanding why such a website is appropriate. Metacognitive scaffolds help students reflect, compare, and revise their process of learning. Teachers can guide students in organizing their learning episodes by asking them to create a learning checklist. The last one is strategic scaffolds, which guide students to identify, select, and evaluate information. At this 
stage, teachers' information literacy is very essential because they have to be able to help students identify valid and reliable English materials in immense digital environments.

Only after contexts, tools, and scaffolds are well-thought-out, can the design instructions of RBL in an EFL class be organized appropriately. The most common generic process of instructional design includes analyze, design, develop, implement, and evaluate, generally known as ADDIE model(A. Brown \& Green, 2011, p. 10). Designing instructions in an EFL class with ADDIE model is appropriate since it is a process that serves as a guiding framework for developing complex educational products(Branch, 2008, p. 2). Additionally, it is claimed that ADDIE model is responsive to whatever established learning goals and contexts (Branch, 2008, p. 4). Thus, implementing RBL within the framework of ADDIE model seems promising as it recognizes contextsin its development phases.

The five ADDIE's phases are subsequent yet iterative (Figure 1). It means that the phases are similar to product development cycles. The cycles are intertwined with evaluation becomes the center of product development process. It indicates that each phase has to be carefully developed and assessed for its quality. In addition, evaluation also becomes grounding rationale

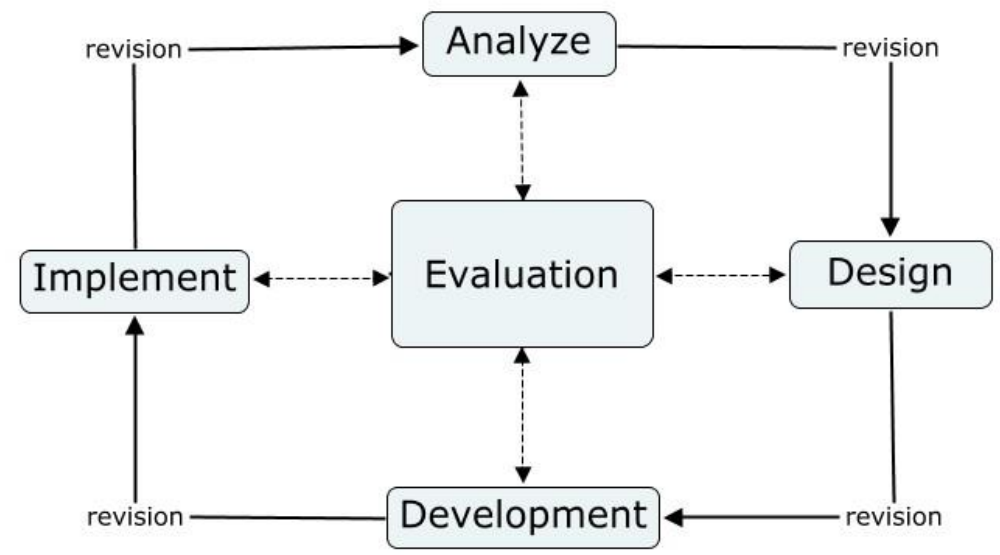

to begin a new cycle of product development.

Figure 1. The Addie Cycle adopted from Branch (2008, p. 2) 
Resource based learning fits very well in ADDIE model. The analyze phase is where RBL is implemented as the delivery system (read: teaching and learning method) in developing an EFL class. Once RBL is selected, the rests of ADDIE phases will follow. As mentioned earlier, evaluation phase is very critical as it is utilized to assess the feasibility of RBL in an EFL class.

\section{Resource Based Learning for Teaching and Learning English as a Foreign Language Class}

General procedures in implementing RBL according to Campbell, Flageolle, Griffith, and Wojcik (2002)include: (1) determine unit goals; (2) determine acceptable students' artifacts; (3) plan the unit thoroughly; (4) gather resources from a variety of formats; (5) generate a timeline for the unit; (6) schedule research time; (7) develop a rubric to assess students' artifacts; (8) evaluate students' performance; and (9) evaluate the unit.

Practically, the implementation of RBL is an iterative process following the principle of ADDIE (figure 2). When implementing RBL inan EFL class, Indonesia's educational contexts should frame the implementation. Thus, Indonesia's English curriculum, as an external context, directs the implementation of RBL. Resource based learning in the EFL class begins with clearly established instructional goals, which are the derivatives of English curriculum. Teachers then design a standard of acceptable artifacts that students need to accomplish. The next procedure is teachers provide appropriate and enough tools that will help students gather resources from digital environments needed to complete the artifacts. During the gathering process, scaffolds should be given to keep students on track such as asking students to always follow the predetermined timeline. Along with all these procedures, teachers evaluate each step carefully to avoid possible mismatch between RBL procedures, learning goals, and students' practices. Next, students' artifacts are assessed based on the pre-determined rubrics. Finally, teachers evaluate the success of RBL-based instructions and make revisions and adjustments for future implementations. 


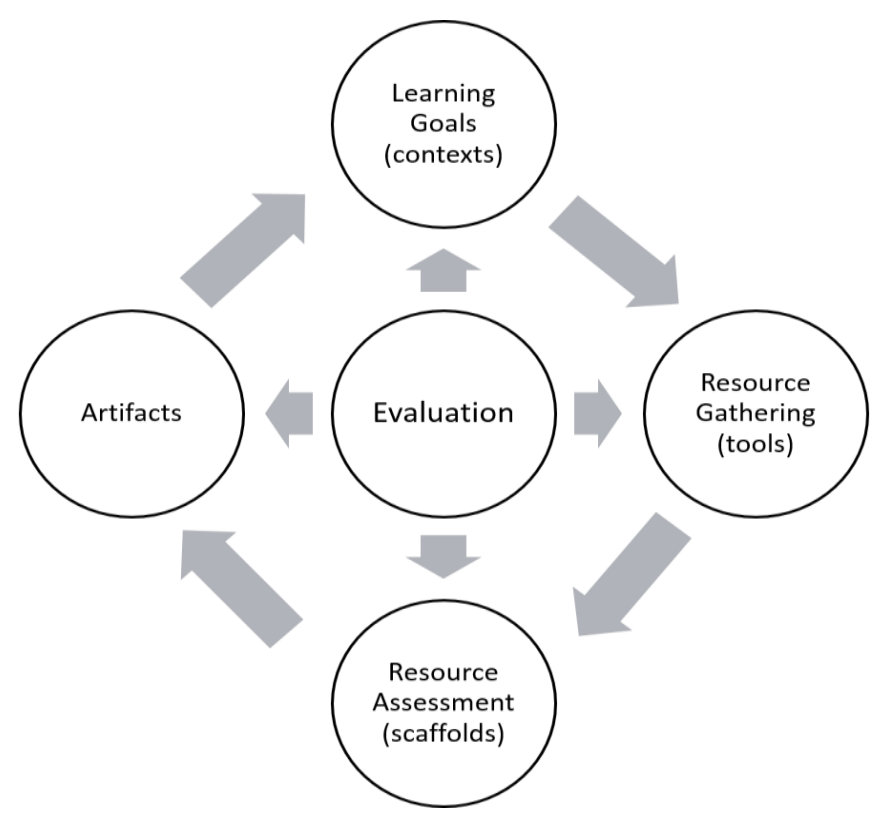

Figure 2. RBL Instructions Cycle in an EFL Class with an adaptation from Branch (2008, p. 2)

Several important notes need to be highlighted regarding the components of RBL instructions in an EFL class. Due to constructivist nature of RBL, teachers need to ascertain that learning goals demonstrate higher order thinking skills and problem solving abilities (Campbell et al., 2002). Although learning goals are the interpretation of English curriculum, they should stimulate students to become active producers of English knowledge and skills.

Artifacts in RBL should be challenging but realistic for students (Campbell et al., 2002). In an English speaking class, for instance, an English drama performance can be a good artifact. Not only do students learn how to act, they also learn how to evaluate their pronunciations and analyze common English expressions. Interestingly, students can explore abundant resources about drama in English with digital technologies.

Creating and following timeline is essential in RBL. A good timeline should guide students to progress through the RBL cycle systematically. It should also set realistic dates and 
allow some time for teachers to provide assistances to students as needed. In the English drama case, for instance, the timeline should clearly determine when students gather information, synthesize information, ask for teacher's assistances, and finally perform the drama.

Since the outcome of RBL instructions is artifacts, rubrics become a better option in assessing students' learning performance than written assessments (Diller \& Phelps, 2008; Panadero \& Jonsson, 2013). Similar to learning goals, teachers should clearly inform the rubrics used to assess students' English learning performance in the beginning of the course meeting. Rubrics contain apparent requirements of final artifacts. Thus, students in the English drama case, for instance, are fully aware of expectations they need to meet if they want to complete the artifact successfully.

Evaluations are as instrumental as other RBL components. Evaluations in RBL consist of two phases. The first phase is evaluating students' artifacts and the second one is evaluating RBL instructions as a whole. If evaluating students' artifacts is to measure students' English learning performance, evaluating RBL instructions is to find out whether or not the instructions are effective, efficient, and feasible. This unit evaluation will then be used to make improvements for future implementations.

Finally, teachers' role receives a special attention in RBL. Unlike their role in more traditional teaching methods, teachers in RBL become coaches, facilitators, and guides as their students gather, analyze, and evaluate information from digital environments (Campbell et al., 2002). Instead of teaching facts, teachers empower students how to learn. In an EFL class, teachers should not claim that their English knowledge is absolute and without flaws, but they should encourage students to explore and construct English facts from the digital world. Additionally, teachers also need to ensure that learning does occur (Beswick, 1979).

\section{CONCLUSIONS}

Resource based learning offers considerable promise for educators in the field of Teaching and Learning English as a Foreign Language (TEFL). The advancement of digital technologies should be embraced as an advantage to improve students' learning experiences. 
English teachers are no longer seen as a single authority of English facts. Students need more democratized ways of learning and digital technologies can accommodate their needs. Given some concerns associated with massive amount of information and its reliability, RBL emerges as an innovative catalyst that guides students in exploring information that is congruent with predetermined instructional goals.

The implementation of RBL in an EFL class is not without any issues. Digital resources present challenges for RBL in light of teachers' and students' digital literacies (Hannafin \& Hill, 2007). Additionally, Barnard and Nash (2005) adds that only those who are information literate can locate information accurately and access information effectively. Thus, for RBL to be successful, educators need to make sure that all components of RBL (contexts, tools, scaffolds) are designed and implemented carefully by bringing various experts such as instructional designers, media specialists, and content experts into play. 


\section{REFERENCES}

Adult Literacy Rate. 2016. Available from The World Bank Retrieved February 15, 2016, from The World Bank http://data.worldbank.org/indicator/SE.ADT.LITR.ZS

Bachore, M. M. 2015. Language Learning through Mobile Technologies: An Opportunity for Language Learners and Teachers. Journal of Education and Practice, 6(31), 50-53.

Bailly, S., Ciekanski, M., \& Guély-Costa, E. 2013. Training Language Teachers to Sustain SelfDirected Language Learning: An Exploration of Advisers' Experiences on a Web-Based Open Virtual Learning Environment. The EUROCALL Review, 21(1), 35-53.

Barnard, A., \& Nash, R. 2005. Information literacy: developing lifelong skills through nursing education. Journal of Nursing Education, 44(11), 505.

Beswick, N. 1979. Resource-Based Learning. London: Heinemann Educational Books.

Branch, R. M. 2008. Instructional Design: the ADDIE Approach: New York; London: Springer.

Breivik, P. S. 1996. Information literacy: When computers aren't enough. Learning and Leading with Technology, 23, 65-67.

Brooks, T. A. 2003. Web search: how the Web has changed information retrieval. Information Research, 8(3), 8-3.

Brown, A., \& Green, T. D. 2011. The Essentials of Instructional Design: Connecting Fundamental Principles with Process and Practice (2nd ed.): Boston: Pearson.

Brown, S., \& Smith, B. 1996. Resource-Based Learning. London: Kogan Page.

Butler, M. 2012. Resource-based learning and course design: A brief theoretical overview and practical suggestions. Law Libr. J., 104, 219.

Campbell, L., Flageolle, P., Griffith, S., \& Wojcik, C. 2002. Resource-based learning. Emerging perspectives on learning, teaching, and technology. Retrieved from http://epltt.coe.uga.edu/index.php?title=Resource-Based_Learning

Chun, D., Smith, B., \& Kern, R. 2016. Technology in language use, language teaching, and language learning. The Modern Language Journal, 100(S1), 64-80.

Clifton, A., \& Mann, C. 2011. Can YouTube enhance student nurse learning? Nurse education today, 31(4), 311-313. 
Counts, E. 2006. From Gertie to gigabytes: revealing the world with digital media. International journal of instructional media, 33(1), 23-32.

Cunningham, D., \& Duffy, T. 1996. Constructivism: Implications for the design and delivery of instruction. Handbook of research for educational communications and technology, 170198.

Cunningham, D., Knight, B., \& Watson, K. 1994. Instructional prescriptions can be hazardous to your pedagogy. Journal of Accelerative Learning and Teaching, 19(1), 17-45.

Diller, K. R., \& Phelps, S. F. 2008. Learning outcomes, portfolios, and rubrics, oh my! Authentic assessment of an information literacy program. portal: Libraries and the Academy, 8(1), 75-89.

Doiron, R., \& Davies, J. 1998. Partners in Learning: Students, Teachers, and the School Library. Englewood, CO: Libraries Unlimited.

Duffy, P. 2008. Engaging the YouTube Google-eyed generation: Strategies for using Web 2.0 in teaching and learning. The Electronic Journal of e-Learning, 6(2), 119-130.

Duncan, R. M. 1995. Piaget and Vygotsky revisited: Dialogue or assimilation? Developmental Review, 15(4), 458-472.

Dybvik, B. J. 2008. An examination of student perceptions of lynda. com software tutorial training. University of Wisconsin-Stout.

Gagné, R. M., Wager, W. W., Golas, K. C., \& Keller, J. M. 2005. Principles of instructional design (5th ed.): Belmont, CA: Thomson/Wadsworth.

Galbreath, J. 1997. The Internet: Past, Present, and Future. Educational Technology, 37(6), 3945.

Giroux, H. A. 2010. Rethinking education as the practice of freedom: Paulo Freire and the promise of critical pedagogy. Policy Futures in Education, 8(6), 715-721.

Hannafin, M. J., \& Hill, J. 2007. Resource-based learning. Handbook of research on educational communications and technology, 3, 525-536. 
Harp, D., \& Tremayne, M. 2006. The gendered blogosphere: Examining inequality using network and feminist theory. Journalism \& Mass Communication Quarterly, 83(2), 247264.

Haycock, C.-A. 1991. Resource-based learning: A shift in the roles of teacher, learner. Nassp Bulletin, 75(535), 15-22.

Hill, J. R., Domizi, D. P., Hannafin, M. J., Kim, M., \& Kim, H. 2007. Teaching and learning in negotiated and informal environments. Handbook of distance education, 271-284.

Hill, J. R., \& Hannafin, M. J. 2001. Teaching and learning in digital environments: The resurgence of resource-based learning. Educational Technology Research and Development, 49(3), 37-52.

Iiyoshi, T., Hannafin, M. J., \& Wang, F. 2005. Cognitive tools and student-centred learning: rethinking tools, functions and applications. Educational Media International, 42(4), 281-296.

Internet Users (per 100 people). 2016. Available from The World Bank Retrieved February 15, 2016, from The World Bank http://data.worldbank.org/indicator/IT.NET.USER.P2

Kellner, D. 2003. Toward a critical theory of education. Democracy \& Nature, 9(1), 51-64.

Kononets, N. 2015. Experience in Implementing Resource-Based Learning in Agrarian College of Management and Law Poltava State Agrarian Academy. Turkish Online Journal of Distance Education, 16(2).

Lee, D. Y., \& Lehto, M. R. 2013. User acceptance of YouTube for procedural learning: An extension of the Technology Acceptance Model. Computers \& Education, 61, 193-208.

Maddux, C. D., \& Johnson, D. L. 1997. The World Wide Web: History, cultural context, and a manual for developers of educational information-based Web sites. Educational Technology, 37(5), 5-12.

McPherson, K. 2006. Wikis and literacy development. Teacher Librarian, 34(1), 67-69.

Nunan, D. 2003. The impact of English as a global language on educational policies and practices in the Asia-Pacific Region. TESOL quarterly, 37(4), 589-613. 
Panadero, E., \& Jonsson, A. 2013. The use of scoring rubrics for formative assessment purposes revisited: A review. Educational Research Review, 9, 129-144.

Reigeluth, C. M., \& Squire, K. 1998. Emerging work on the new paradigm of instructional theories. EDUCATIONAL TECHNOLOGY-SADDLE BROOK NJ-, 38, 41-47.

Richards, J. C. 1998. Beyond Training: Perspectives on Language Teacher Education. Cambridge, England: Cambridge University Press.

Savery, J. R., \& Duffy, T. M. 1995. Problem based learning: An instructional model and its constructivist framework. Educational Technology, 35(5), 31-38.

Sharma, P., \& Hannafin, M. J. 2007. Scaffolding in technology-enhanced learning environments. Interactive learning environments, 15(1), 27-46.

So, W. W. M., \& Ching, F. N. Y. 2012. Online resource-based learning environment: Case studies in primary classrooms. Paper presented at the Asia-Pacific Forum On Science Learning And Teaching.

Son, J.-B., Robb, T., \& Charismiadji, I. 2011. Computer literacy and competency: A survey of Indonesian teachers of English as a foreign language. Computer-Assisted Language Learning Electronic Journal (CALL-EJ), 12(1), 26-42.

Tan, E. 2013. Informal learning on YouTube: Exploring digital literacy in independent online learning. Learning, Media and Technology, 38(4), 463-477.

Thompson, C. 2011. How Khan Academy is changing the rules of education. Wired Magazine, $126,1-5$.

Yu, H., Abrizah, A., \& Sani, M. K. J. A. 2016. Information literacy through resource-based learning: Malaysian teachers' conception and instructional practices. Malaysian Journal of Library \& Information Science, 21(2016), 53-67. 